\title{
PROSPECTIVE HEALTH RISK OF EXPOSURE TO FINE PARTICULATE MATTER AND ITS ELEMENTAL COMPOSITION IN SHOE INDUSTRIES IN AGRA
}

\author{
Mansi Gupta, Renuka Saini, Ajay Taneja \\ Department of Chemistry, Dr. Bhim Rao Ambedkar University, Agra, India \\ Email: ataneja5@hotmail.com
}

Abstract -

The present study shows the current scenario of the prospective health risk of exposure to fine particulate matter and its composition at industry level. The indoor and outdoor sampling of fine particulate matter was conducted in residential site (Industry-1) and road site (Industry-2) shoe industry in Agra city. The average concentration of PM sizes accounted in indoor during sampling duration were $30.11 \mu \mathrm{g} / \mathrm{m}^{3} \pm 10.29 \mu \mathrm{g} / \mathrm{m}^{3}$ for $\mathrm{PM}_{1.0}, 47.79 \mu \mathrm{g} / \mathrm{m}^{3} \pm 45.49 \mu \mathrm{g} / \mathrm{m}^{3}$ for $\mathrm{PM}_{2.5}$ and $90.15 \mu \mathrm{g} / \mathrm{m}^{3} \pm 33.61$ $\mu \mathrm{g} / \mathrm{m}^{3}$ for $\mathrm{PM}_{10}$ at industry-1, and $7.66 \mu \mathrm{g} / \mathrm{m}^{3} \pm 1.86 \mu \mathrm{g} / \mathrm{m}^{3}$ for $\mathrm{PM}_{1.0}, 22.24 \mu \mathrm{g} / \mathrm{m}^{3} \pm 3.69 \mu \mathrm{gg} / \mathrm{m}^{3}$ for $\mathrm{PM}_{2.5}$ and 60.89 $\mu \mathrm{g} / \mathrm{m}^{3} \pm 49.06 \mu \mathrm{g} / \mathrm{m}^{3}$ for $\mathrm{PM}_{10}$ at industry-2. The concentration of the three components of $P M\left(\mathrm{PM}_{1.0}, \mathrm{PM}_{2.5}, \mathrm{PM}_{10}\right)$ was found to be highest in industry-1 in comparison to industry-2. The full-day variation of fine particulate matter concentration and indoor meteorological parameters were also monitored. The average mass concentrations of various fraction of $\mathrm{PM}\left(\mathrm{PM}_{1.0}\right.$, $\mathrm{PM}_{2.5}, \mathrm{PM}_{10}$ ) were collected at indoor and outdoor environment in two leather (shoe) small scale industries by APM 550. After acid digestion, quantification of 16 major metals $\mathrm{Cu}, \mathrm{Ba}, \mathrm{Cd}, \mathrm{Cr}, \mathrm{Fe}, \mathrm{Mn}, \mathrm{Ni}, \mathrm{Pb}, \mathrm{Al}, \mathrm{K}, \mathrm{Ca}, \mathrm{Na}, \mathrm{Mg}, \mathrm{As}$, $\mathrm{Co}$ and $\mathrm{Zn}$ was done using ICP-AES (Inductive Couple Plasma-Atomic Emission Spectroscopy) and AAS (Atomic Absorption spectroscopy).

Keywords: Air pollution, Indoor air quality (IAQ), Fine particulate matter, heavy metals, correlation analysis, Occupational Exposure Levels.

\section{INTRODUCTION}

The air we breathe is a mixture of gases, solid and liquid substances. Air pollution occurs when the air contains substances in such quantities that could harm the comfort or health of humans and animals, or could damage plants and material [1,2]. Industries and auto exhausts are responsible for rising discomfort, increasing airborne diseases and deterioration of an artistic and cultural heritage in urban and industrial area [3]. The fine particles in ambient air have been reported to be associated with many health problems [4]. The fractions smaller than $2.5 \mu \mathrm{m}\left(\mathrm{PM}_{2.5}\right)$ are getting more and more attention worldwide, which can result in the prolonged exposure, promoting or aggravating health problems [5]. Because the $\mathrm{PM}_{2.5}$ has a long residential time of several days to weeks in atmosphere, it can travel hundreds to thousands of kilometers. Previous studies indicated that smaller particles of $\mathrm{PM}_{2.5}$ are water soluble and hygroscopic, and make them bio-available $[6,7]$. On the other hand, the $\mathrm{PM}_{2.5}$ has high concentrations of toxic trace metals, such as chromium $(\mathrm{Cr})$, cadmium $(\mathrm{Cd})$, manganese (Mn), nickel (Ni), lead (Pb), arsenic (As), zinc (Zn), etc [8]. Those toxic heavy metals incorporated with $\mathrm{PM}_{2.5}$ may enter the body through inhalation and have been suggested as causative agents associated with adverse respiratory health effects.

\section{EXPERIMETAL}

Agra, the city of Taj Mahal, $\left(27.18^{\circ} \mathrm{N}, 78.02^{\circ} \mathrm{E}\right)$ is located in north central part of Indian state of Uttar Pradesh located on banks of the river Yamuna[9] (Fig.1) The area of Agra district is $4,041 \mathrm{sq}$. km. with a population of $4,418,797$ (male $54 \%$ and female $46 \%$ ) [10].Literacy rate of Agra district is $71.58 \%$ [11].

\section{A. Industrial Layout}

Agra has 7200 small Industrial Units, which are spread all over the district (Table-I). The leather industry is among the most traditional and original industry of Agra. 


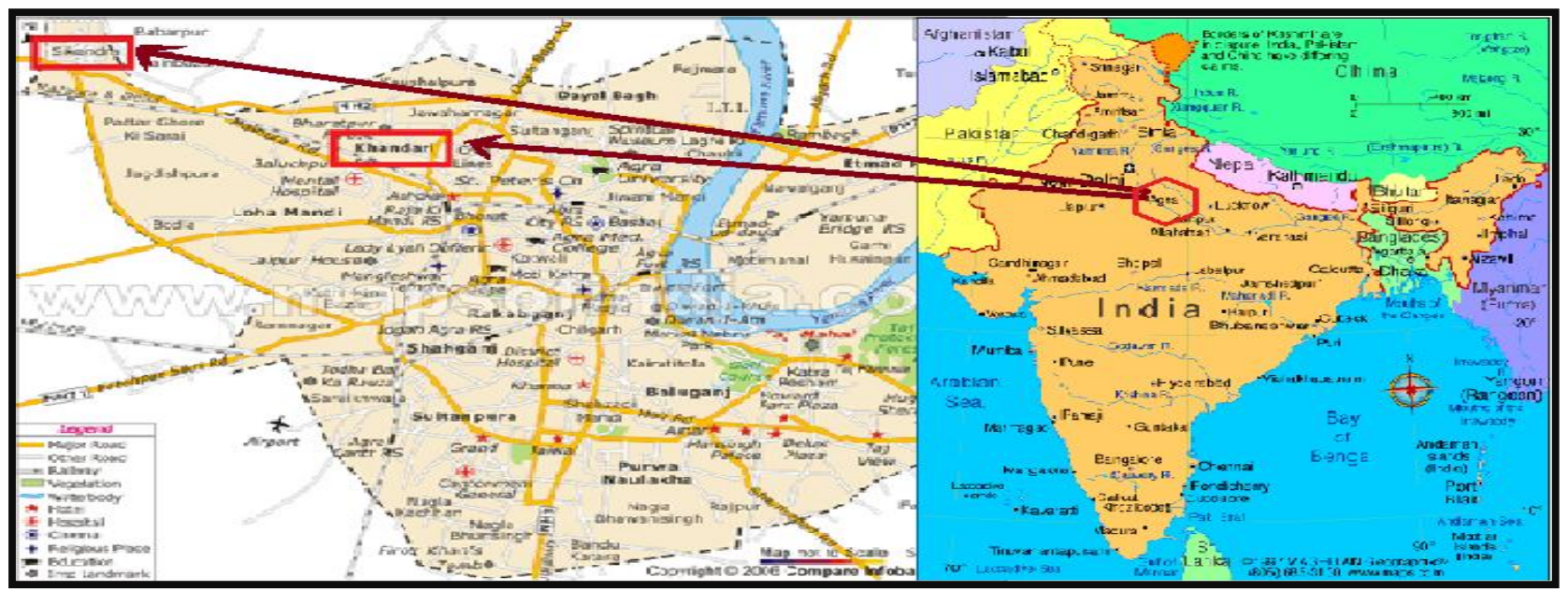

Fig.1: Site Map of Agra

Table 1: Number and types of Industries in Agra

\begin{tabular}{|c|c|c|c|c|c|c|c|}
\hline S.No & Kind of SSI Units & $\begin{array}{c}\text { Number of } \\
\text { SSI units } \\
\text { till 2006 }\end{array}$ & $\begin{array}{c}\text { Increased } \\
\text { Units in } \\
2006- \\
2007\end{array}$ & $\begin{array}{c}\text { Increased } \\
\text { Units in } \\
2007-2008\end{array}$ & $\begin{array}{c}\text { Increased } \\
\text { Units in } \\
2008- \\
2009\end{array}$ & $\begin{array}{c}\text { Increased } \\
\text { Units in } \\
2009-2010\end{array}$ & $\begin{array}{c}\text { Total No of } \\
\text { SSI Units in } \\
2010\end{array}$ \\
\hline $\mathbf{1 .}$ & $\begin{array}{c}\text { Non-Metallic } \\
\text { Mineral Products }\end{array}$ & 341 & - & - & - & - & 341 \\
\hline $\mathbf{2 .}$ & Metal Products & 166 & 10 & 28 & 1 & - & 205 \\
\hline $\mathbf{3 .}$ & $\begin{array}{c}\text { Machinery \& Part } \\
\text { Except Electrical }\end{array}$ & 253 & - & 51 & 36 & 24 & 364 \\
\hline $\mathbf{4 .}$ & $\begin{array}{c}\text { Electrical } \\
\text { Machinery \& } \\
\text { Apparatus }\end{array}$ & 63 & - & 8 & - & - & 71 \\
\hline $\mathbf{5}$ & $\begin{array}{c}\text { Repairing \& } \\
\text { Servicing Industry } \\
\text { Chemical \& } \\
\text { Chemical }\end{array}$ & 1719 & 183 & - & 210 & 195 & 2306 \\
\hline $\mathbf{6 .}$ & 113 & 1 & 5 & 3 & 5 & 127 \\
\hline $\mathbf{7 .}$ & $\begin{array}{c}\text { Rubber \& Plastic } \\
\mathbf{8 .}\end{array}$ & 194 & 2 & 43 & 5 & 6 & 250 \\
\hline $\mathbf{9 .}$ & $\begin{array}{c}\text { Leather Products } \\
\text { Paper Product \& } \\
\text { Printing }\end{array}$ & 263 & 54 & 174 & 174 & 163 & 828 \\
\hline $\mathbf{1 0 .}$ & $\begin{array}{c}\text { Beverage and } \\
\text { Tobacco } \\
\text { products[12] }\end{array}$ & 04 & - & - & - & - & 04 \\
\hline
\end{tabular}

\section{B. Number of Footwear Units in Agra}

Agra is the hub of shoe industry. There are about 60 organized footwear units, 3000 tiny manufacturing units and about 30,000 households' artisans units. Above 1.5 lakh pair of shoes is manufactured per day in Agra by the cottage, small scale and medium scale footwear unit (Table-II).

\section{Sample Collection}

Indoor and outdoor samples of fine particles from shoe industry were collected using airborne particulate matter sampler (APM 550, Envirotech, New Delhi, India) on $47 \mathrm{~mm}$ diameter polytetrafluoroethylene (PTFE) filter papers. APM 550 runs at a constant flow rate of 16.6 I/minute. The instrument was generally positioned in manufacturing units where occupants of the industry 
spend most of their time. Inlet head was positioned as close as possible to head height, which is the breathing zone for the occupants. The air exchange rate was measured on sampling site by using (YES-206) indoor air quality monitor from (Young Environment Systems, Inc., Canada). GRIMM 31-channel portable aerosol spectrometer model no.1.109 was used for monitoring the indoor mass concentration of $\mathrm{PM}_{2.5}$ at a flow rate of $1.2 \mathrm{~L}$ min $^{-1} \pm 5 \%$ constant with controller for continuous measurement during the sampling period. The obtained mean mass concentration from the GRIMM-1.109 PAS was regularly compared with a medium volume APM 550, filter-based sampler.

Table 2: Location of major sites for shoe industry present in Agra

\begin{tabular}{|c|c|c|}
\hline S. No. & $\begin{array}{l}\text { Name of the } \\
\text { Major Area }\end{array}$ & Name of Mohallas \\
\hline 1. & Sadar Bhalti & $\begin{array}{l}\text { DoliKar, Ghatia Mannu Bhanja, Nala } \\
\text { Mantola, Teelanandram and Mantola }\end{array}$ \\
\hline 2. & Nai ki Mandi & $\begin{array}{l}\text { Khattara Nail, Chota Galivpura, } \\
\text { Haveli-Ka-Berka, Choti Adoye. }\end{array}$ \\
\hline 3. & Shahganj & $\begin{array}{l}\text { Prakash Nagar, Prem Nagar, Rui Ki } \\
\text { Mandi, Bharakambha, Bhogipura, } \\
\text { Prithwinath \& Namak Ki Mandi }\end{array}$ \\
\hline 4. & Lohamandi & $\begin{array}{c}\text { Jagdishpura, Gadi Badoria, } \\
\text { Madiyakatra }\end{array}$ \\
\hline 5. & Taliya & $\begin{array}{l}\text { Nala Kajipara, Kotwali Basti, } \\
\text { Chakkipat }\end{array}$ \\
\hline 6. & Agra Cononment & Nandpura, Nayi Basti, Pakkisarar \\
\hline 7. & Collectorate & Sunderpara, Idgah \\
\hline 8. & $\begin{array}{c}\text { Agra Mathura } \\
\text { Road (Bye-Pass) }\end{array}$ & $\begin{array}{c}\text { Khandari, Sheetla Road, Sikandra, } \\
\text { Artoni [12]. }\end{array}$ \\
\hline
\end{tabular}

\section{Chemical Analysis}

$9 \mathrm{ml}$ of hydrochloric acid $(\mathrm{HCl} 37 \%)$ and $3 \mathrm{ml}$ of nitrate $\left(\mathrm{HNO}_{3} 65 \%\right)$ were mixed together and then poured into a Teflon cup. Samples were then heated to $50^{\circ} \mathrm{C}$ on a hot plate for $2 \mathrm{~h}$. Samples after digestion on the hotplate were then filtered. After filtration, the sample solution was added to $0.2 \% \mathrm{HNO}_{3}$ to produce a $100 \mathrm{ml}$ solution. The samples were maintained at $4^{\circ} \mathrm{C}$ in a refrigerator and analysis was conducted using inductively coupled plasma - atomic emission spectrometer (ICPAES, Perkin Elmer Optima 2100 Plasma Emission Spectrometer) analysis. Concentrations of $\mathrm{Cu}, \mathrm{Ba}, \mathrm{Cd}$, $\mathrm{Cr}, \mathrm{Fe}, \mathrm{Mn}, \mathrm{Ni}, \mathrm{Pb}, \mathrm{Al}, \mathrm{K}, \mathrm{Ca}, \mathrm{Na}, \mathrm{Mg}, \mathrm{As}$, $\mathrm{Co}$ and $\mathrm{Zn}$ were determined.

\section{RESULTS AND DISCUSSIONS}

\section{A. Meteorological Parameters}

Meteorological conditions which shown in Table-III play a predominant factor governing the concentration variation of particulate matter [13].

Table 3: Average metrological parameters measured during sampling

\begin{tabular}{|c|c|c|c|c|c|c|c|}
\hline & \multicolumn{3}{|c|}{ Indoor } & \multicolumn{4}{c|}{ Outdoor } \\
\hline $\begin{array}{c}\text { Paramete } \\
\mathbf{r} \\
\begin{array}{c}\text { Measure } \\
\mathbf{d}\end{array}\end{array}$ & $\begin{array}{c}\mathrm{CO}_{2} \\
(\mathrm{ppm})\end{array}$ & $\begin{array}{c}\text { Ventil } \\
\text { ation } \\
\text { Rate } \\
(\mathbf{l p s})\end{array}$ & $\begin{array}{c}\mathrm{Temp} . \\
\left({ }^{\circ} \mathrm{C}\right)\end{array}$ & $\begin{array}{c}\mathrm{CO}_{2} \\
(\mathrm{ppm})\end{array}$ & $\begin{array}{c}\text { Temp. } \\
\left({ }^{\circ} \mathrm{C}\right)\end{array}$ & $\begin{array}{c}\text { R.H. } \\
(\%)\end{array}$ & $\begin{array}{c}\text { Wind } \\
\mathbf{5 p e e} \\
\mathbf{d} \\
(\mathrm{m} / \mathbf{s})\end{array}$ \\
\hline Mean & 642.40 & 22.03 & 36.71 & 497.33 & 37.49 & 58.6 & 4.0 \\
\hline Median & 620.27 & 22.16 & 37.70 & 491.21 & 37.32 & 56.3 & 4.1 \\
\hline Minimum & 556.78 & 15.53 & 36.28 & 487.15 & 36.67 & 45.6 & 1.6 \\
\hline Maximum & 772.30 & 28.28 & 37.10 & 519.75 & 38.7 & 79.7 & 6.6 \\
\hline $\begin{array}{c}\text { Skewnes } \\
\mathbf{s}\end{array}$ & 1.33 & -0.13 & -0.01 & 1.83 & 0.53 & 1.12 & -0.18 \\
\hline \begin{tabular}{c} 
Stdev \\
\hline
\end{tabular} & 91.64 & 5.27 & 0.44 & 15.15 & 0.98 & 11.2 & 1.79 \\
\end{tabular}

Skewness=3(Mean-Median)/Standard deviation

Table-IV Shows the PM concentrations are inversely proportional to the wind speed (PM concentration increases with decrease in wind speed). The wind speed and the turbulence in the ambient atmosphere mainly determine the air borne PM residence time at the ground surface and the rate of formation of secondary PM. Increase in the percentage of humidity increases the PM level. As the relative humidity increases. Therefore, the humidity affects the concentrations of coarse and fine particle at the study region [14].

Table-4 Correlation Matrix between $\mathrm{PM}_{2.5}$, WS (m/s), Relative Humidity (\%) and Temperature

\begin{tabular}{|c|c|c|c|c|}
\hline & $\mathrm{PM}_{2.5}$ & WS (m/s) & $\% \mathrm{RH}$ & Temp. $^{\circ} \mathrm{C}$ \\
\hline $\mathbf{P M}_{2.5}$ & 1 & & & \\
\hline WS (m/s) & -0.9213 & 1 & & \\
\hline$\%$ RH & 0.8473 & -0.8030 & 1 & \\
\hline Temp. ${ }^{\circ} \mathbf{C}$ & 0.1428 & 0.2438 & -0.0489 & 1 \\
\hline
\end{tabular}

\section{B. Mass Concentration of Particulate Matter}

Sampling of $\mathrm{PM}_{10}, \mathrm{PM}_{2.5}$, and $\mathrm{PM}_{1.0}$ was done with GRIMM Aerosol Spectrometer (GRIMM 1.109), with a flow rate (2L/min) from 9 June 2014 to 19 June 2014 at Industry-1 which is situated at Galana Road, Sikandra, Agra and Industry-2 which is situated at Transport Nagar, Agra. Monitoring was done in inside and outside of the industries. Measurements were done during working 
hours ( 8 am to $6 \mathrm{pm}$ ). The average mass concentrations of various fraction of $\mathrm{PM}\left(\mathrm{PM}_{1.0}, \mathrm{PM}_{2.5}, \mathrm{PM}_{10}\right)$ were collected at indoor environment in two leather (shoe) small scale industries. Table-3 presents the average, median, standard deviation, maximum and minimum concentration along with skewness for particles $\mathrm{PM}_{1.0}$, $\mathrm{PM}_{2.5}$, and $\mathrm{PM}_{10}$, in inside the leather industry at industry1 and industry-2 during sampling.

Table 5: Statistical summary of the particulate matter trends at indoor environment in leather (shoe) industries

\begin{tabular}{|c|c|c|c|c|c|c|}
\hline \multicolumn{7}{|c|}{ Industry-1 } \\
\hline $\begin{array}{c}\text { Polluta } \\
\text { nt }\end{array}$ & $\begin{array}{c}\text { Avera } \\
\text { ge }\end{array}$ & Max. & $\begin{array}{c}\text { Med } \\
\text { ian }\end{array}$ & Min. & Skew & SD \\
\hline PM-1.0 & 30.11 & 64.2 & 28.4 & 15 & 1.04 & 10.29 \\
\hline PM-2.5 & 47.79 & 187 & 32.1 & 6.4 & 1.24 & 45.49 \\
\hline PM-10 & 90.15 & 227.3 & 89.4 & 31.7 & 0.99 & 33.61 \\
\hline \multicolumn{7}{|c|}{ Industry-2 } \\
\hline $\begin{array}{c}\text { Polluta } \\
\text { nt }\end{array}$ & $\begin{array}{c}\text { Avera } \\
\text { ge }\end{array}$ & Max. & $\begin{array}{c}\text { Med } \\
\text { ian }\end{array}$ & Min. & Skew & SD \\
\hline $\begin{array}{c}\text { PM-1.0 } \\
7.66\end{array}$ & 12.3 & 8.15 & 4.6 & $\begin{array}{c}0.003 \\
7\end{array}$ & 1.86 \\
\hline PM-2.5 & 22.24 & 38.6 & 22.3 & 14.4 & 1.21 & 3.69 \\
\hline PM-10 & 60.89 & 419.5 & 51.2 & 33.2 & 2.45 & 49.06 \\
\hline
\end{tabular}

The average concentration of PM sizes accounted in indoor during sampling duration were $30.11 \mu \mathrm{g} / \mathrm{m}^{3} \pm 10.29 \mu \mathrm{g} / \mathrm{m}^{3} \quad$ for $\quad \mathrm{PM}_{1.0}, \quad 47.79$ $\mu \mathrm{g} / \mathrm{m}^{3} \pm 45.49 \mu \mathrm{g} / \mathrm{m}^{3}$ for $\mathrm{PM}_{2.5}$ and $90.15 \mu \mathrm{g} / \mathrm{m}^{3} \pm 33.61$ $\mu \mathrm{g} / \mathrm{m}^{3}$ for $\mathrm{PM}_{10}$ at industry-1, and $7.66 \mu \mathrm{g} / \mathrm{m}^{3} \pm 1.86 \mu \mathrm{g} / \mathrm{m}^{3}$ for $\mathrm{PM}_{1.0}, 22.24 \mu \mathrm{g} / \mathrm{m}^{3} \pm 3.69 \mu \mathrm{g} / \mathrm{m}^{3}$ for $\mathrm{PM}_{2.5}$ and 60.89 $\mu \mathrm{g} / \mathrm{m}^{3} \pm 49.06 \mu \mathrm{g} / \mathrm{m}^{3}$ for $\mathrm{PM}_{10}$ at industry-2.

The concentration of all the three components of PM $\left(\mathrm{PM}_{1.0}, \mathrm{PM}_{2.5}, \mathrm{PM}_{10}\right)$ was found to be highest in industry-1 in comparison to industry-2 (Fig.2). In industry-1 regular cutting, casting, adhesive, stitching, pressing and packing was seen more due to more number of workers in comparison to the industry-2. Moreover, to view the shape of distribution, skewness was calculated. This showed that the mean concentrations of PM was positively skewed i.e. the data is distributed to the right of the median, at both the industries. Skewness was higher in industry-2 $\left(0.003,1.21\right.$ and 2.45 for $\mathrm{PM}_{1.0}, \mathrm{PM}_{2.5}$ and $\mathrm{PM}_{10}$ ).

Such positive skewness depicts that there are some higher values that are not offset by corresponding lower values in the data distribution, that tend to make the mean greater than the median. Thus by using the relationship between the mean and median, the extent up to which the data distribution is skewed can be measured. It is called as the Pearsonian coefficient of skewness. It ranges between -3 to +3 and skewness zero means a normal frequency curve or perfectly symmetrical distribution [15].

Furthermore, to compare mean concentration at both industries, paired sample T Test was applied. This showed that $p$-value for $\mathrm{PM}_{1.0}, \mathrm{PM}_{2.5}$ and $\mathrm{PM}_{10}$ at industry-1 was $\leq 0.06$ which signifies $94 \%$ significant difference in their mean values. Similarly $p$-value for $\mathrm{PM}_{1.0}, \mathrm{PM}_{2.5}$ and $\mathrm{PM}_{10}$ at industry-2 was $\leq 0.13$ which signifies $87 \%$ significant difference in their mean values. The above results indicate that the particulate size decreasing with a significant difference in their mean values. Thus, we can say that PM concentrations are found higher surrounded by so many residential houses and somewhat decline with the distance from polluted areas i.e. road areas. The higher values of PM at industry-1 which had more workers strength and more activity as compare to industry-2, which is situated at road side and surrounded by so many commercial shops and attributed to road dust, diesel/petrol vehicular emissions, as the major sources of pollution. Nearby commercial activities was also one of the reasons, which pollutes outdoor air.

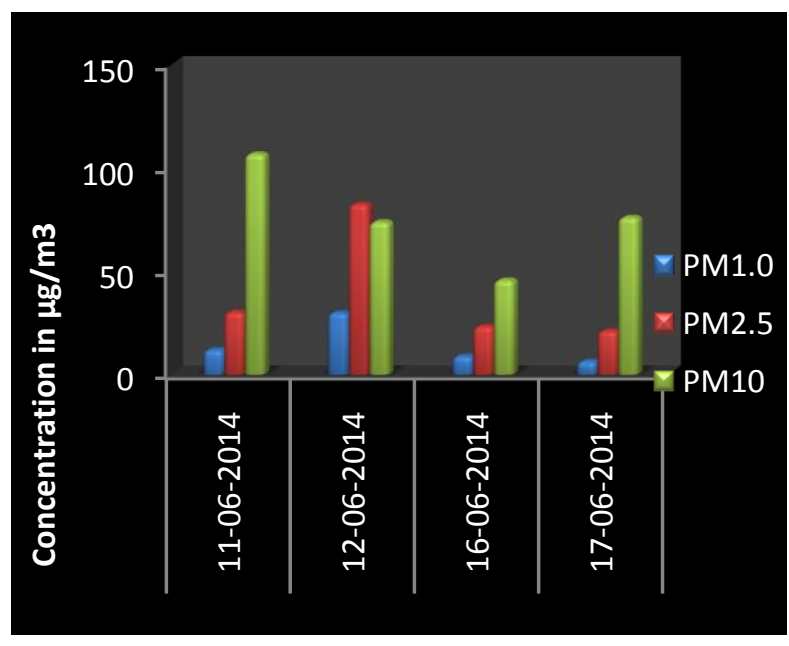

Fig.2: Concentration of PM inside at two leather (shoe) small scale industries

\section{Air Quality Standard}

In India, indoor environment air quality standards have not been recommended yet, therefore the concentration of $\mathrm{PM}_{10}$ and $\mathrm{PM}_{2.5}$ were compared with WHO, 2010 standards (Table-VI) and NAAQS for two 
different leather industries. Standards for $\mathrm{PM}_{1.0}$ have not been proposed by any of the agencies till now.

Table-6: Comparison of Particulate Matter Concentration with WHO and NAAQS Standards

\begin{tabular}{|c|c|c|c|c|}
\hline Parameters & WHO Standards[16] & NAAQS Standards[17] & Present Study & Comments (permissible limits) \\
\hline \multirow[t]{2}{*}{$\mathrm{PM}_{10}$} & \multirow[t]{2}{*}{$\begin{array}{l}20 \mu \mathrm{g} / \mathrm{m}^{3} \text { (Annual) } \\
50 \mu \mathrm{g} / \mathrm{m}^{3}(24 \mathrm{hrs})\end{array}$} & \multirow[t]{2}{*}{$\begin{array}{l}60 \mu \mathrm{gg} / \mathrm{m}^{3} \text { (Annual) } \\
100 \mu \mathrm{g} / \mathrm{m}^{3} \text { (24 hrs) }\end{array}$} & $90.15 \mu \mathrm{g} / \mathrm{m}^{3}$ (Ind.-1) & $\begin{array}{l}\text { Above from WHO and Lower } \\
\text { from NAAQS }\end{array}$ \\
\hline & & & $60.89 \mu \mathrm{g} / \mathrm{m}^{3}$ (Ind.-2) & $\begin{array}{l}\text { Above from WHO and Lower } \\
\text { from NAAQS }\end{array}$ \\
\hline \multirow[t]{2}{*}{$\mathrm{PM}_{2.5}$} & \multirow[t]{2}{*}{$\begin{array}{l}10 \mu \mathrm{g} / \mathrm{m}^{3} \text { (Annual) } \\
25 \mu \mathrm{g} / \mathrm{m}^{3} \text { (24 hrs) }\end{array}$} & \multirow[t]{2}{*}{$\begin{array}{l}40 \mu \mathrm{g} / \mathrm{m}^{3} \text { (Annual) } \\
60 \mu \mathrm{g} / \mathrm{m}^{3} \text { (24 hrs) }\end{array}$} & $47.79 \mu \mathrm{g} / \mathrm{m}^{3}$ (Ind.-1) & $\begin{array}{l}\text { Above from WHO and Lower } \\
\text { from NAAQS }\end{array}$ \\
\hline & & & $22.24 \mu \mathrm{g} / \mathrm{m}^{3}$ (Ind.-2) & $\begin{array}{l}\text { Lower from Both WHO and } \\
\text { NAAQS }\end{array}$ \\
\hline
\end{tabular}

The mean of the $\mathrm{PM}_{10}$ is 1.8 and 1.2 times higher than the standards of WHO in industry-1 and industry- 2 it is 0.9 and 0.6 times lower than the standards of NAAQS, while the concentration of $\mathrm{PM}_{2.5}$ is 1.9 times higher than WHO standard in industry- 1 and 0.8 times lower than WHO standard in industry- 2 whereas it is 0.79 times and 0.37 times lower than the standards of NAAQS. This result is probably due to the activities of buffing, pasting, cutting and shaving in leather industries. $\mathrm{PM}_{10}$ and $\mathrm{PM}_{2.5}$ concentration may produce some potential health effect on workers who are exposed.

High level of exposure are associated with chronic respiratory and cardiovascular health effects including a decline in lung function, an increase in blood plasma viscosity, a reduction of heart rate variability and multiple signs of inflammation. Research studies suggest that exposure to PM may be linked to brain damage by chronic inflammatory processes as well [18]. The present study clearly suggest that the inhalable particulate matter released from leather industries are not simply inert dust, but also contain mineral dust with a high content of potential toxic elements such as $\mathrm{Fe}, \mathrm{Cu}, \mathrm{Zn}$. $\mathrm{Cr}, \mathrm{Co}, \mathrm{Cd}$ and $\mathrm{Pb}$ [19].

\section{Time Series Data}

During the study period, time series data of PM concentration was also taken, which showed higher concentration during the morning hours in all the two industries because of more activities performed by high strength of workers. Also in the morning office hour's, large numbers of vehicle pass on the road adjacent to these industries and changing the shift of workers at that time. In industry-1 (Fig.3) the average concentration of PM in morning hours was higher than afternoon and evening hours.

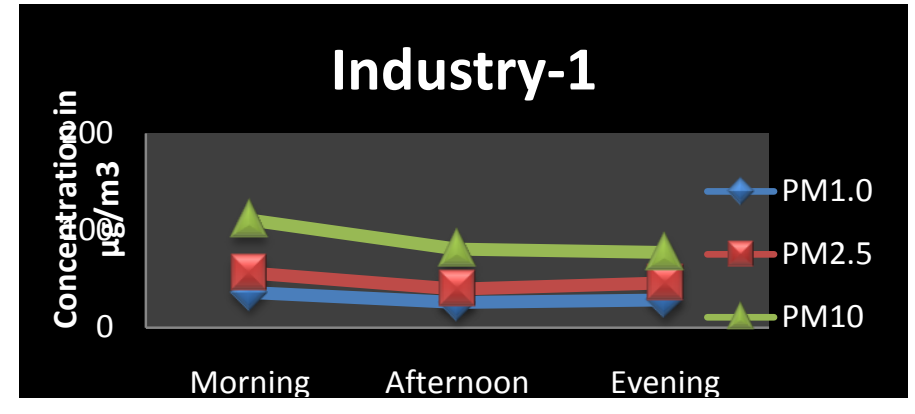

Fig.3: Time series data show in industry-1

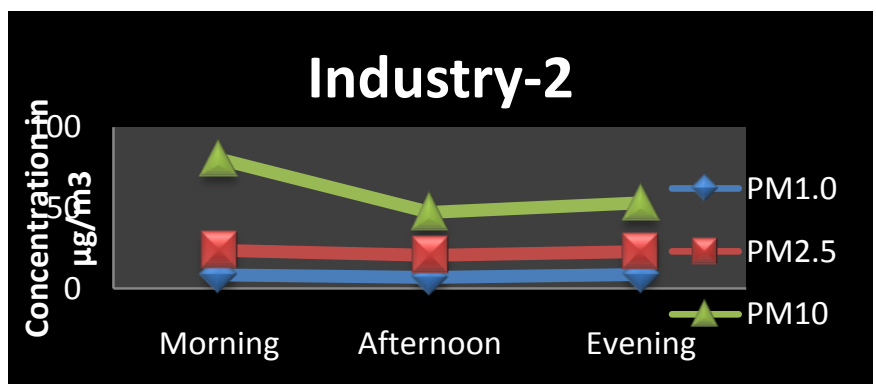

Fig.4: Time series data show in industry-2

The maximum concentration of PM was found at the morning hours. In industry-2 (Fig.4) the average concentration of PM in morning hours was higher than afternoon and evening hour, due to maximum activities at this time. This included changing the shift of workers as well as cutting, casting, stitching, pressing and packing activity performed.

\section{E. Elemental Concentration of the $\mathrm{Pm}_{2.5}$ Fraction}

The eight samples were collected from two leather (shoe) industries. Analysis of Sixteen heavy metals $\mathrm{Cu}$, $\mathrm{Ba}, \mathrm{Cd}, \mathrm{Cr}$, Fe, Mn, Ni, Pb, Al, K, Ca, Na, Mg, As and Zn was done on ICP-AES (Table-VII and VIII). Higher mean was obtained for Fe and $\mathrm{Zn}$ from industry-1 outdoor and indoor $(187.085 \mu \mathrm{g} / \mathrm{l}$ and $6.723 \mu \mathrm{g} / \mathrm{l})$ and $(5.145 \mu \mathrm{g} / \mathrm{l}$ and $102.485 \mu \mathrm{g} / \mathrm{l})$ and Industry-2 outdoor and indoor (276.909 
$\mu \mathrm{g} / \mathrm{l}$ and $29.071 \mu \mathrm{g} / \mathrm{l})$ and $(6.003 \mu \mathrm{g} / \mathrm{l}$ and $180.123 \mu \mathrm{g} / \mathrm{l}) \quad$ respectively.

Table-7: Statistical analysis of heavy metal concentration of indoor and outdoor PM in leather industry-1 ( $\mu \mathrm{g} / \mathrm{lor} \mathrm{ppb}$ )

\begin{tabular}{|l|l|l|l|l|l|l|l|l|}
\hline \multicolumn{9}{|c|}{ Industry-1 } \\
\hline \multicolumn{9}{|c|}{ Outdoor } \\
\hline
\end{tabular}

Table-8: Statistical analysis of heavy metal concentration of indoor and outdoor PM in leather industry-2 ( $\mu \mathrm{g} / \mathrm{lor} \mathrm{ppb}$ )

\begin{tabular}{|c|c|c|c|c|c|c|c|c|}
\hline \multicolumn{9}{|c|}{ Industry-2 } \\
\hline \multicolumn{5}{|c|}{ Outdoor } & \multicolumn{4}{|c|}{ Indoor } \\
\hline & Mean & Max & Min & SD & Mean & Max & Min & SD \\
\hline $\mathrm{Cu}$ & 1.707 & 2.148 & 1.266 & 0.623 & 2.001 & 2.003 & 1.002 & 0.281 \\
\hline $\mathrm{Zn}$ & 29.071 & 53.77 & 4.372 & 34.923 & 6.003 & 7.003 & 5.001 & 1.875 \\
\hline $\mathrm{Fe}$ & 276.987 & 521.39 & 32.428 & 345.745 & 180.123 & 278.023 & 82.009 & 138.568 \\
\hline $\mathrm{Pb}$ & 1.257 & 1.902 & 0.612 & 0.912 & 1.023 & 1.034 & 1.023 & 0.162 \\
\hline $\mathrm{Cd}$ & 0.115 & 0.221 & $\mathrm{ND}$ & 0.156 & $\mathrm{ND}$ & $\mathrm{ND}$ & $\mathrm{ND}$ & 0.173 \\
\hline Co & 0.023 & 0.028 & 0.019 & 0.006 & ND & ND & $\mathrm{ND}$ & 0.003 \\
\hline $\mathrm{Al}$ & 11.105 & 12.33 & 9.887 & 1.732 & 6.987 & 7.056 & 6.034 & 0.311 \\
\hline $\mathrm{Ba}$ & 0.666 & 1.088 & 0.244 & 0.596 & 1.125 & 1.045 & 1.349 & 0.357 \\
\hline $\mathrm{Cr}$ & $\mathrm{ND}$ & $\mathrm{ND}$ & $\mathrm{ND}$ & $\mathrm{ND}$ & $\mathrm{ND}$ & $\mathrm{ND}$ & $\mathrm{ND}$ & $\mathrm{ND}$ \\
\hline $\mathrm{Ni}$ & 0.815 & 0.991 & 0.632 & 0.255 & 1.326 & 1.067 & 1.006 & 0.007 \\
\hline $\mathrm{Mn}$ & 0.904 & 1.809 & ND & 1.279 & ND & $\mathrm{ND}$ & $\mathrm{ND}$ & 0.071 \\
\hline $\mathrm{K}$ & 0.004 & 0.0065 & 0.003 & 0.002 & $\mathrm{ND}$ & $\mathrm{ND}$ & $\mathrm{ND}$ & 0.003 \\
\hline $\mathrm{Ca}$ & 0.085 & 0.114 & 0.056 & 0.041 & $\mathrm{ND}$ & $\mathrm{ND}$ & $\mathrm{ND}$ & 0.042 \\
\hline $\mathrm{Na}$ & 0.856 & 0.117 & 0.053 & 0.045 & $\overline{N D}$ & $\mathrm{ND}$ & $\mathrm{ND}$ & 0.023 \\
\hline $\mathrm{Mg}$ & 0.0123 & 0.018 & 0.005 & 0.009 & $\mathrm{ND}$ & $\mathrm{ND}$ & $\mathrm{ND}$ & 0.005 \\
\hline As & 0.109 & 0.123 & 0.097 & 0.017 & ND & ND & $\overline{N D}$ & 0.064 \\
\hline
\end{tabular}

The percentage contribution of $\mathrm{Fe}$, Cu was higher in outdoor environment of industry- 1 whereas $\mathrm{Ba}, \mathrm{Fe}$ and $\mathrm{Cu}$ were higher in indoor environment of industry-1. Fe, $\mathrm{Pb}, \mathrm{Ba}$ and $\mathrm{Ni}$ were higher in outdoor environment of industry-2, while $\mathrm{Fe}, \mathrm{Zn}, \mathrm{Cu} \mathrm{Pb}$ and $\mathrm{Al}$ were higher in indoor environment of industry-2, due to unauthorized coal burning, domestic fuel burning and very fine particulate matter travelling from industries [20]. According to Sharma et al., (2004)[21] vehicles in major cities of India are estimated to account for $70 \%$ of 
respective total pollution load and some additional toxic air pollutants emitted by motor vehicles comprise cadmium, chromium and lead.

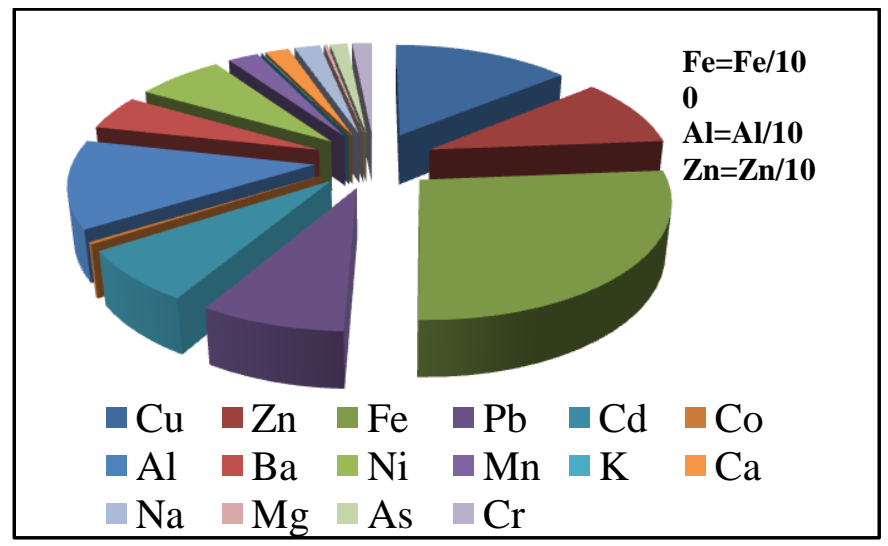

Fig.5A: Contribution of each element in industry-1 (outdoor)

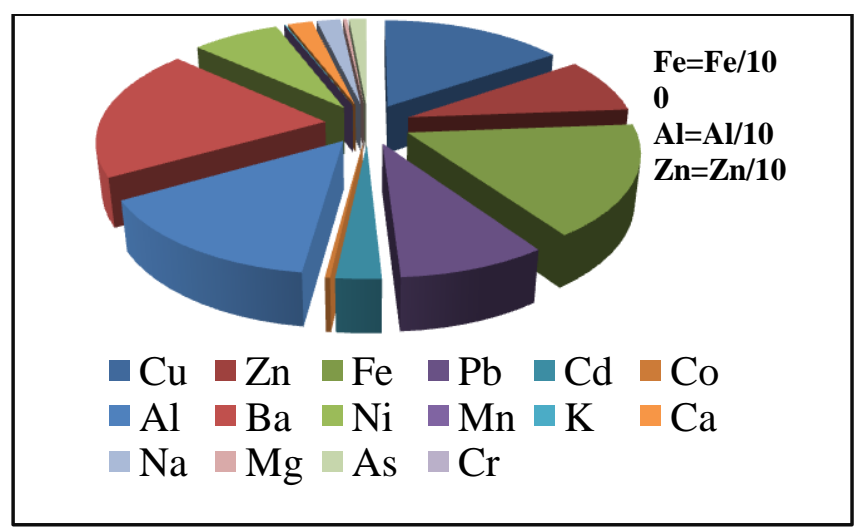

Fig.5B: Contribution of each element in industry-1 (indoor)

The percentage contribution of these elements in $\mathrm{PM}_{2.5}$ followed the

trend $\mathrm{Fe}>\mathrm{Cu}>\mathrm{Al}>\mathrm{Zn}>\mathrm{Pb}>\mathrm{Cd}=\mathrm{Ni}>\mathrm{Ba}>\mathrm{Mn}=\mathrm{Na}=\mathrm{Ca}=\mathrm{Cr}>\mathrm{As}>\mathrm{Mg}=\mathrm{Co}=\mathrm{K}$ (Fig. $5 \mathrm{~A}$ ) at outdoor and $\mathrm{Ba}>\mathrm{Fe}>\mathrm{Al}=\mathrm{Cu}>\mathrm{Pb}>\mathrm{Zn}>\mathrm{Ni}>\mathrm{Cd}>\mathrm{Ca}=\mathrm{Na}>\mathrm{As}>\mathrm{Mg}=\mathrm{Co}=\mathrm{K}=\mathrm{Mn}=\mathrm{Cr}$ (Fig. 5B) at indoor in industry-1.

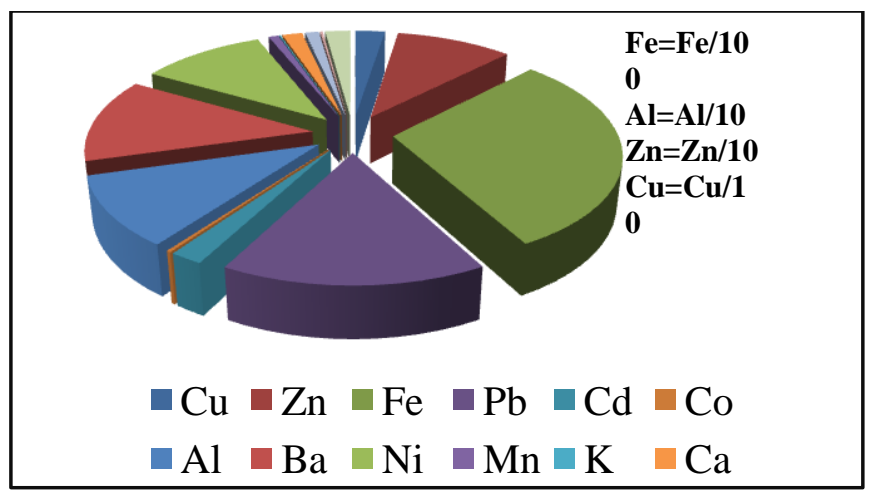

Fig.5C: Contribution of each element in industry-2 (outdoor)

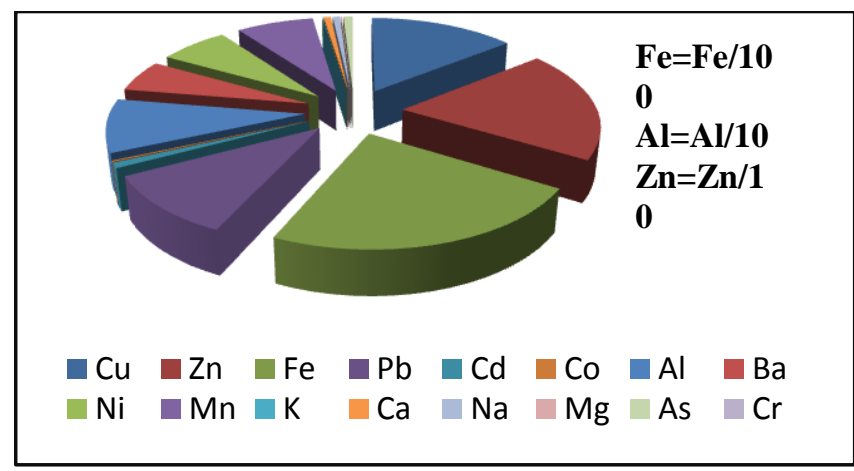

Fig.5D: Contribution of each element in industry-2 (indoor)

The percentage contribution of these elements in $\mathrm{PM}_{2.5}$ followed the trend $\mathrm{Fe}>\mathrm{Pb}>\mathrm{Ba}>\mathrm{Ni}>\mathrm{Al}=\mathrm{Zn}>\mathrm{Cu}>\mathrm{Ca}=\mathrm{As}=\mathrm{Cd}>\mathrm{Na}=\mathrm{Mn}>\mathrm{Co}=\mathrm{Mg}=\mathrm{K}=\mathrm{Cr}$ (Fig. $\quad 5 \mathrm{C}$ ) at outdoor and $\mathrm{Fe}>\mathrm{Zn}>\mathrm{Cu}>\mathrm{Pb}>\mathrm{A} \mid>\mathrm{Mn}>\mathrm{Ni}>\mathrm{Ba}>\mathrm{Ca}=\mathrm{As}=\mathrm{Na}=\mathrm{Cd}>\mathrm{Co}=\mathrm{Mg}=\mathrm{K}=\mathrm{Cr}$ (Fig. 5D) at indoor in industry-2.

\section{F. Correlation Matrix}

By evaluating the bivariate Pearson correlation coefficient for all the elements present in $\mathrm{PM}_{2.5}$ collected in shoe industry $A$ and $B$, Table-IX indicates indoor and outdoor inter elemental association. The values $R \geq 0.5$ show the stronger correlation. $\mathrm{Cu}$ is strongly correlated with $\mathrm{Zn}(\mathrm{r}=0.74)$, $\mathrm{Fe}(\mathrm{r}=0.79), \mathrm{Pb}(\mathrm{r}=0.99), \mathrm{Ni}(\mathrm{r}=0.98), \mathrm{Mn}$ $(r=0.72)$, As $(r=0.76)$; the sources of copper are road dust, vehicular exhaust and biomass burning [24, 29]. $\mathrm{Zn}$ is strongly correlated with $\mathrm{Fe}(\mathrm{r}=0.87), \mathrm{Pb}(\mathrm{r}=0.83)$, Co $(r=0.78), \mathrm{Al}(r=0.80), \mathrm{Ni}(0.87)$, and $\mathrm{Mn}(r=0.99)$; sources of zinc are vehicle exhaust, road dust, fossil fuel combustion and biomass burning [22, 25, 26]. Fe is positively correlated with $\mathrm{Pb}(\mathrm{r}=0.84), \mathrm{Ni}(\mathrm{r}=0.87)$, and $\mathrm{Mn}$ $(r=0.90) ; F e$ indicates soil origin and road resuspension in correlation with $\mathrm{Pb}$ outdoor traffic polluted resuspended road dust enters indoors at few industry. The symptoms chest pain, shortness of breath, upper respiratory problems also gives an indication of asthma among workers [30]. $\mathrm{Pb}$ is strongly correlated with $\mathrm{Ni}(\mathrm{r}=1), \mathrm{Mn}$ $(r=0.80)$, and As ( $r=0.65)$; the sources of lead vehicle exhaust, biomass burning, fossil fuels combustion and road [23, 27, 28]. $\mathrm{Ni}$ is strongly correlated with $\mathrm{Mn}$ $(r=0.84)$ and $A s(r=0.61)$; sources of nickel are fossils fuel combustion, biomass burning, road dust and vehicle exhaust $[27,28] . \mathrm{Cd}$ is strongly correlated with $\mathrm{Ca}$ $(r=0.70), \mathrm{Cr}(\mathrm{r}=0.99), \mathrm{Na}(\mathrm{r}=0.81), \mathrm{Mg}(\mathrm{r}=0.70)$, and $\mathrm{PM}_{2.5}$ $(r=0.8)$; vehicular emissions, and industrial emission, automobile lubricants activities are the possible sources of cadmium in ambient air [22]. 
Table-9: Correlation Matrix of Heavy Metals at indoor and outdoor in leather industries

\begin{tabular}{|c|c|c|c|c|c|c|c|c|c|c|c|c|c|c|c|c|c|}
\hline & $\mathbf{C u}$ & $\mathbf{Z n}$ & $\mathbf{F e}$ & $\mathbf{P b}$ & Cd & Co & Al & $\mathbf{B a}$ & $\mathbf{C r}$ & $\mathbf{N i}$ & Mn & $\mathbf{K}$ & $\mathbf{C a}$ & $\mathbf{N a}$ & $\mathbf{M g}$ & As & PM2.5 \\
\hline $\mathbf{C u}$ & 1 & & & & & & & & & & & & & & & & \\
\hline $\mathbf{Z n}$ & 0.73 & 1 & & & & & & & & & & & & & & & \\
\hline $\mathrm{Fe}$ & 0.79 & 0.87 & 1 & & & & & & & & & & & & & & \\
\hline $\mathbf{P b}$ & 0.98 & 0.82 & 0.84 & 1 & & & & & & & & & & & & & \\
\hline Cd & -0.64 & -0.36 & -0.11 & -0.62 & 1 & & & & & & & & & & & & \\
\hline Co & 0.18 & 0.78 & 0.65 & 0.31 & 0.21 & 1 & & & & & & & & & & & \\
\hline Al & 0.22 & 0.81 & 0.47 & 0.36 & -0.16 & 0.89 & 1 & & & & & & & & & & \\
\hline Ba & -0.15 & -0.21 & -0.61 & -0.16 & -0.66 & -0.39 & 0.04 & 1 & & & & & & & & & \\
\hline $\mathrm{Cr}$ & -0.54 & -0.28 & 0.01 & -0.52 & 0.99 & 0.24 & -0.15 & -0.74 & 1 & & & & & & & & \\
\hline $\mathbf{N i}$ & 0.97 & 0.86 & 0.87 & 0.99 & -0.57 & 0.38 & 0.41 & -0.21 & -0.47 & 1 & & & & & & & \\
\hline Mn & 0.71 & 0.99 & 0.91 & 0.79 & -0.26 & 0.82 & 0.79 & -0.31 & -0.17 & 0.83 & 1 & & & & & & \\
\hline $\mathbf{K}$ & -0.81 & -0.94 & -0.98 & -0.86 & 0.22 & -0.71 & -0.61 & 0.47 & 0.12 & -0.93 & -0.96 & 1 & & & & & \\
\hline $\mathbf{C a}$ & -0.98 & -0.81 & -0.77 & -0.99 & 0.71 & -0.27 & -0.37 & 0.04 & 0.61 & -0.98 & -0.77 & 0.82 & 1 & & & & \\
\hline $\mathbf{N a}$ & -0.89 & -0.39 & -0.43 & -0.82 & 0.81 & 0.25 & 0.11 & -0.15 & 0.73 & -0.78 & -0.32 & 0.44 & 0.85 & 1 & & & \\
\hline Mg & -0.98 & -0.63 & -0.69 & -0.95 & 0.69 & -0.03 & -0.11 & 0.07 & 0.61 & -0.93 & -0.58 & 0.78 & 0.96 & 0.94 & 1 & & \\
\hline As & 0.75 & 0.12 & 0.39 & 0.65 & -0.47 & -0.43 & -0.46 & -0.15 & -0.39 & 0.65 & 0.09 & -0.31 & -0.62 & -0.88 & -0.82 & 1 & \\
\hline PM2.5 & -0.08 & -0.07 & 0.36 & -0.09 & 0.79 & 0.19 & -0.26 & -0.95 & 0.86 & -0.06 & 0.03 & -0.19 & 0.23 & 0.35 & 0.13 & 0.09 & 1 \\
\hline
\end{tabular}

Bold value in parenthesis indicates correlation is significant at the 0.05 level (2-tailed).

Table-10: Comparison of present study element levels with other indoor concentration of industrial areas worldwide

\begin{tabular}{|c|c|c|c|c|c|c|c|c|c|c|}
\hline Site & $\begin{array}{l}\mathrm{PM}_{2.5} / \mathrm{T} \\
\mathrm{SP}\end{array}$ & $\begin{array}{l}\mathrm{Cr} \\
\mu \mathrm{g} / \mathrm{m}^{3}\end{array}$ & $\begin{array}{l}\mathrm{Cu} \\
\mu \mathrm{g} / \mathrm{m}^{3}\end{array}$ & $\begin{array}{l}\mathrm{Fe} \\
\mu \mathrm{g} / \mathrm{m}^{3}\end{array}$ & $\begin{array}{l}\mathrm{Pb} \\
\mu \mathrm{g} / \mathrm{m}^{3}\end{array}$ & $\begin{array}{l}\mathrm{Zn} \\
\mu \mathrm{g} / \mathrm{m}^{3}\end{array}$ & $\begin{array}{l}\mathrm{Cd} \\
\mu \mathrm{g} / \mathrm{m}^{3}\end{array}$ & $\begin{array}{l}\text { Al } \\
\mu \mathrm{g} / \mathrm{m}^{3}\end{array}$ & $\begin{array}{l}\mathrm{Ni} \\
\mu \mathrm{g} / \mathrm{m}^{3}\end{array}$ & References \\
\hline Agra, U.P. & $\mathrm{PM}_{2.5}$ & $\begin{array}{l}0.03 \\
\mu \mathrm{g} / \mathrm{l}\end{array}$ & $\begin{array}{l}1.29 \\
\mu \mathrm{g} / \mathrm{l}\end{array}$ & $\begin{array}{l}186.7 \\
\mu \mathrm{g} / \mathrm{l}\end{array}$ & $\begin{array}{l}0.83 \\
\mu \mathrm{g} / \mathrm{l}\end{array}$ & $\begin{array}{l}11.7 \\
\mu \mathrm{g} / \mathrm{l}\end{array}$ & $\begin{array}{l}0.23 \\
\mu g / l\end{array}$ & $\begin{array}{l}8.71 \\
\mu \mathrm{g} / \mathrm{l}\end{array}$ & $\begin{array}{l}0.59 \\
\mu g / l\end{array}$ & Present study \\
\hline $\begin{array}{l}\text { Wah Cantt, } \\
\text { Pakistan }\end{array}$ & TSP & 0.068 & 1.11 & 1.70 & 0.27 & 3.49 & - & - & - & $\begin{array}{ll}\begin{array}{l}\text { Nazir et } \\
(2011)[36]\end{array} & \text { al., } \\
\end{array}$ \\
\hline $\begin{array}{l}\text { Colombo, } \\
\text { South Brazil }\end{array}$ & $\mathrm{PM}_{2.5}$ & - & 0.0 & 0.308 & - & - & 2.30 & 3.30 & 0.17 & $\begin{array}{l}\text { Godoi et al., } \\
(2008)[37]\end{array}$ \\
\hline $\begin{array}{l}\text { Guangzhou, } \\
\text { China }\end{array}$ & $\mathrm{PM}_{2.5}$ & 0.007 & 0.036 & 0.414 & 0.185 & 0.407 & - & - & - & $\begin{array}{l}\text { Hong et al. } \\
(2007)[38]\end{array}$ \\
\hline $\begin{array}{l}\text { Mexico City, } \\
\text { Mexico }\end{array}$ & $\mathrm{PM}_{2.5}$ & 0.033 & 0.97 & 0.644 & 0.039 & 0.365 & - & - & - & $\begin{array}{l}\text { Ahumada } \\
\text { et al., (2007)[39] }\end{array}$ \\
\hline $\begin{array}{l}\text { Minneapoli- } \\
\text { st. } \quad \text { Paul, } \\
\text { USA }\end{array}$ & $\mathrm{PM}_{2.5}$ & 0.001 & 0.004 & 0.063 & 0.003 & 0.010 & - & - & - & $\begin{array}{l}\begin{array}{l}\text { Adegate } \\
(2007)[40]\end{array} \\
\text { et }\end{array}$ \\
\hline $\begin{array}{l}\text { Hangfors, } \\
\text { Sweeden }\end{array}$ & $\mathrm{PM}_{2.5}$ & - & 0.001 & 0.027 & 0.004 & 0.025 & - & - & - & $\begin{array}{l}\begin{array}{l}\text { Molnar et al., } \\
(2005)[41]\end{array} \\
\end{array}$ \\
\hline $\begin{array}{l}\text { Goteborg, } \\
\text { Sweeden }\end{array}$ & $\mathrm{PM}_{2.5}$ & - & 0.009 & 0.039 & 0.003 & 0.017 & - & - & - & $\begin{array}{l}\text { Molnar et al., } \\
(2006)[42]\end{array}$ \\
\hline $\begin{array}{l}\text { Sohar } \\
\text { industrial } \\
\text { State, Oman }\end{array}$ & TSP & 0.004 & 0.005 & - & 0.030 & 2.060 & - & - & - & $\begin{array}{l}\text { Abdul-wahabe et } \\
\text { al., (2004)[43] }\end{array}$ \\
\hline $\begin{array}{l}\text { southeast } \\
\text { china }\end{array}$ & $\mathrm{PM}_{2.5}$ & $\begin{array}{l}1152 \\
\mathrm{ng} / \mathrm{m}^{3}\end{array}$ & $\begin{array}{l}126 \\
\mathrm{ng} / \mathrm{m}^{3}\end{array}$ & & $\begin{array}{l}392 \\
\mathrm{ng} / \mathrm{m}^{3}\end{array}$ & $\begin{array}{l}924 \\
\mathrm{ng} / \mathrm{m}^{3}\end{array}$ & & & $\begin{array}{l}7.2 \\
\mathrm{ng} / \mathrm{m}^{3}\end{array}$ & $\begin{array}{l}\text { Deng et al., (2006) } \\
\text { [44] }\end{array}$ \\
\hline
\end{tabular}

$\mathrm{Co}$ is strongly correlated with $\mathrm{Al}(\mathrm{r}=0.90)$ and $\mathrm{Mn}$ $(r=0.83)$; a strong correlation is seen in between $\mathrm{Al}$ and $\mathrm{Mn}(\mathrm{r}=0.80)$; the main contributor of aluminium is the motor-vehicle emission. About $13 \%$ of atmospheric aluminium is attributed to anthropogenic emissions [20]. $\mathrm{Cr}$ is strongly correlated with $\mathrm{Ca}(\mathrm{r}=0.61), \mathrm{Na}(\mathrm{r}=0.74), \mathrm{Mg}$ $(r=0.60)$ and $P_{2.5}(r=0.86)$. The sources of chromium are road dust, dyes and pigments, for greatly increasing resistance and durability of metals and chrome plating, leather tanning, and wood preserving. Manufacturing, disposal of products or chemicals containing chromium, or fossil fuel burning release chromium to the air, vehicular emission and metal processing also contribute for emission in atmosphere [23]. $\mathrm{K}$ is strongly correlated with $\mathrm{Ca}(\mathrm{r}=0.83)$ and $\mathrm{Mg}(\mathrm{r}=0.70) ; \mathrm{K}$ also has many sources, such as biomass burning, coal/charcoal burning, 
soil dust, and even traffic exhaust emissions in small amounts [31, 32], $\mathrm{Na}$ is strongly correlated with $\mathrm{Mg}$ $(r=0.95)$; $\mathrm{Mg}$ is positively correlated with $\mathrm{Cr}(\mathrm{r}=0.60)$. Along these probabilities, metal processes like polishing was seen in leather industry. $\mathrm{Mn}$ and $\mathrm{Pb}$ are also associated with $\mathrm{Zn}(\mathrm{r}=0.99$ and 0.82 ) indoors, which may due to the emissions of paints, varnishes usage, in leather industry, along with polluted road dust [33]. The high correlations between heavy metals in air may reflect the fact that these heavy metals had similar pollution levels and similar pollution sources such as shaving, buffing and anthropogenic activities [34, 35].

\section{G. Comparison of Present Studies with Other Studies}

The comparison of average values of the elements in study was done with various studies done in the indoor and outdoor of industrial areas located in other part of world. It is evident that the metal ( $\mathrm{Fe}, \mathrm{Zn}$ and $\mathrm{Al}$ ) concentration of $\mathrm{PM}_{2.5}$ in our study is higher than other studies in the world as shown in Table-X.

\section{H. Assessment of Occupational Exposure Levels}

In order to have some idea of the possible effect of the adverse IAQ on the workers health in leather industry, a relationship between the past health records and present increase in symptoms were investigated by analyzing the 35 questionnaire, as shown in Table-XI. Shoe workers were exposed to perilous condition for 80 to 90 hour/week without proper personal protective equipments.

On the basis of questionnaire survey Fig.6 was plotted to show the percentage of symptoms that were commonly found in the workers exposed to the shoe (shaving and buffing) dust in these two leather industries.

These symptoms were found higher in industry-1 shoe workers than that at industry-2 shoe workers. drinking habits were found 0.5 times higher in industry-1 shoe workers and 0.3 times higher smoking habits in industry-2 shoe workers. Though workers have to go outside the industry for smoking. Because smoking was prohibited in shoe industry. Above health symptoms can be associated with industry-1 and industry-2 shoe workers. This is mainly because workers working in small scale industry did not wear any protective equipment due to negligence or not being aware of the benefits of the protective equipment. Thus there is need to differentiate types of particulate matter and their controlling measures

Table:11 Symptom of workers in the leather (shoe) industry based on questionnaire survey

\begin{tabular}{|c|c|c|}
\hline & \multicolumn{2}{|c|}{ (N=35) } \\
\hline $\begin{array}{c}\text { Sifficulty in } \\
\text { breathing }\end{array}$ & 25 & Industry 2 \\
\hline Dry Throat & 20 & 18 \\
\hline Back pain & 18 & 16 \\
\hline Dizziness & 7 & 8 \\
\hline Itching & 5 & 7 \\
\hline Sneezing & 10 & 15 \\
\hline High stress & 20 & 19 \\
\hline Eye irritation & 10 & 25 \\
\hline Headache & 20 & 20 \\
\hline Drowsiness & 18 & 17 \\
\hline Cold and flu & 17 & 18 \\
\hline Allergies & 7 & 9 \\
\hline Heart disease & 17 & 18 \\
\hline Liver problem & 17 & 18 \\
\hline $\begin{array}{c}\text { Smoking } \\
\text { (outside }\end{array}$ & 20 & 26 \\
\hline Blood Pressure & 17 & 17 \\
\hline Drinking & 34 & 17 \\
\hline
\end{tabular}

\section{CONCLUSIONS}

In this study, Prospective Health Risk of Exposure to Fine Particulate Matter and its Elemental Composition was found in Shoe Industries in Agra. Aaverage concentration of PM sizes accounted in indoor during sampling duration were $30.11 \mu \mathrm{g} / \mathrm{m}^{3} \pm 10.29 \mu \mathrm{g} / \mathrm{m}^{3}$ for $\mathrm{PM}_{1.0}, \quad 47.79 \mu \mathrm{g} / \mathrm{m}^{3} \pm 45.49 \mu \mathrm{gg} / \mathrm{m}^{3}$ for $\mathrm{PM}_{2.5}$ and $90.15 \mu \mathrm{g} / \mathrm{m}^{3} \pm 33.61 \mu \mathrm{g} / \mathrm{m}^{3}$ for $\mathrm{PM}_{10}$ at industry-1, and $7.66 \mu \mathrm{g} / \mathrm{m}^{3} \pm 1.86 \mu \mathrm{g} / \mathrm{m}^{3}$ for $\mathrm{PM}_{1.0}, 22.24 \mu \mathrm{g} / \mathrm{m}^{3} \pm 3.69$ $\mu \mathrm{g} / \mathrm{m}^{3}$ for $\mathrm{PM}_{2.5}$ and $60.89 \mu \mathrm{g} / \mathrm{m}^{3} \pm 49.06 \mu \mathrm{g} / \mathrm{m}^{3}$ for $\mathrm{PM}_{10}$ at industry-2. The mean of the $\mathrm{PM}_{10}$ is 4.5 and 3.04 times higher than the standards of WHO in industry-1 and industry-2. While the concentration of $\mathbf{P M}_{2.5}$ is $\mathbf{4 . 7 8}$ and 2.24 times higher than WHO standard in industry-1 
and industry-2. As this is a short term study and due to the scarcity of such a kind of work, more study is needed to support this database and examine the range and various health effects linked with these indoor and outdoor air pollutants.

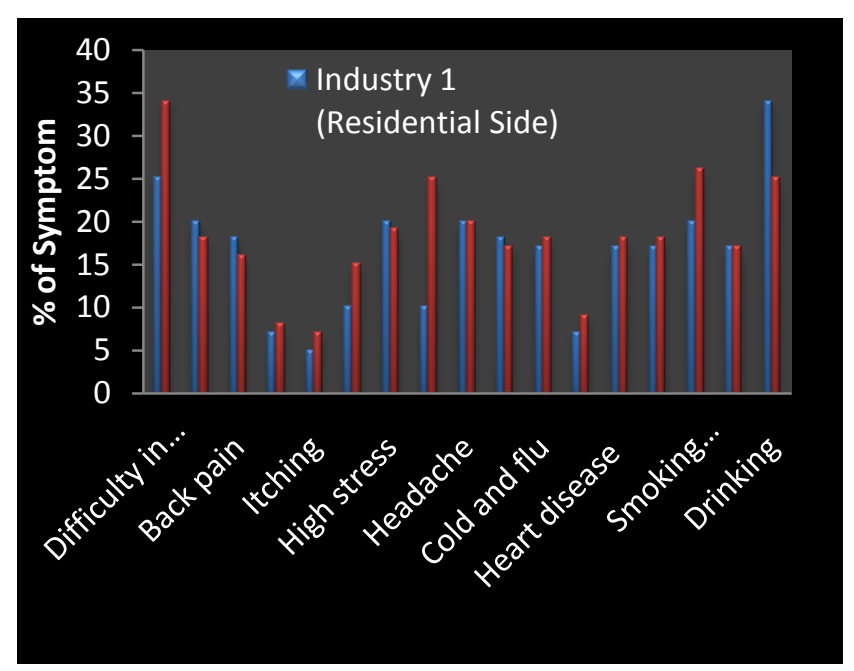

Fig.6: Survey Analysis on the basis of Health Effects

\section{RECOMMENDATIONS}

The workers working in small scale or medium scale industries do not wear proper protective equipment. This is either due to workers being uneducated or due to noncaring attitude. Some solutions can be provided to industries which could help them reduce the amount of respiratory particulate matter. Exhaust ventilation should be used, Direct skin contact should be prevented by gloves, wearing respiratory protection during cleanup is very essential, and Education awareness programs for workers should be instituted about hazard of exposure to leather particulate matter.

\section{ACKNOWLEDGEMENTS}

The authors would like to express their special gratitude to Department of Chemistry, Dr. Bhim Rao Ambedkar University, Agra, India for providing all necessary facilities required for this work. One of the authors acknowledges the University Grant Commission (UGC), New Delhi for Funding (Project No: F.15-45/12 $(S A-I I))$. We would also like to thank to the owners and occupants of the industry for their help and in assisting in this work.

\section{REFERENCES}

[1] Alias, M., Hamzah, Z. and Kenn, L.S., "PM10 and Total suspended particulates (TSP) measurements in various power stations", The Malayasian Journal of Analytical Sciences, 11., 2007, 255-261

[2] Hung, H., MacLeod, M., Guardans, R., Scheringer, M., Barra, R., Harner, T., and Zhang, G. "Toward the next generation of air quality monitoring: Persistent organic pollutants," Atmospheric Environment, 80., 2013, 591-598

[3] Rao, S., Ku, J., Berman, S., Zhang, D., and Mao, H. (2003). "Summertime characteristics of the atmospheric boundary layer and relationships to ozone levels over the eastern United States."Pure Applied Geophysics, 160., 2003, 21-55

[4] Kim J.J., Smorodinsky S, Lipsett M, Singer BC, Hodgson AT, Ostro B. "Traffic-related air pollution near busy roads the East Bay children's respiratory health study". American Journal of Respiratory and Critical Care Medicine , 170., 2004, 520-526

[5] Figueroa D.A., Rodríguez-Sierra C.J., Jiménez-Velez B.D. "Concentrations of $\mathrm{Ni}$ and $\mathrm{V}$, other heavy metals, arsenic, elemental and organic carbon in atmospheric fine particles $\left(\mathrm{PM}_{2.5}\right)$ from Puerto Rico". Toxicology and Industrial Health 22., 2006, 87-99

[6] Raes F, Dingenen RV, Vignati E, Wilson J, Putaud JP, Seinfeld JH, Adams P. "Formation and cycling of aerosols in the global troposphere". Atmospheric Environment 34., 2000, 4215-4240.

[7] Heal M.R., Hibbs L.R., Agius R.M., Beverland I.J. "Total and water-soluble trace metal content of urban background $\mathrm{PM}_{10}, \mathrm{PM}_{2.5}$, and black smoke in Edinburgh, UK". Atmospheric Environment 39., 2005, 1417-1430

[8] Singh M., Jaques P.A., Sioutas, C. "Size distribution and diurnal characteristics of particle-bound metals in source and receptor sites of the Los Angeles Basin". Atmospheric Environment 36., 2002, 1675-1689

[9] Pipal, S. A., Kulshrestha, A., and Taneja, A., Characterization and morphological analysis of airborne $\mathrm{PM}_{2.5}$ and $\mathrm{PM}_{10}$ in Agra located in north central India. Atmospheric Environment, 45., 2011 3621-3630

[10] http://www.census.2011.co.in/news/300_agra_census_201 1 highlights.html visited on 23/08/2014

[11] http://www.census.2011.co.in/census/district/517-agra.html visited on 23/08/2014

[12] http://www.ediindia.org/DSR/Foot wear cluster-visited on 26/08/2014

[13] Taneja, A., Saini, R., and Maish, A., "Indoor air quality of houses located in the urban environment of Agra, India",Annals of New York Academy Science, 1140., 2008, 228-24

[14] Srimuruganandam, B., Nagendra, S. M. S., "Impact of meteorology on roadside Ambient Particulate Matter Concentrations", Modern Traffic and Transportation Engineering Research, 2., 3., 2013, 141-152

[15] Freund, J. E., "Modern Elementary Statistics, Sixth edition, Prentice-Hall, Inc., Englewood Cliffs, New Jersey 1984, 07632 
[16] WHO, "Air Quality Guidelines", http://www.who.int/phe/health/_topics/outdoor_apg/ en/index.html, Global Updates 2005

[17] National Ambient Air Quality Standard, "Central Pollution Central Board, India 2009

[18] Ranft, U., Schikowski, T., Sugiri, D., Krutman, J., Kramer, U., "Long term exposure to traffic-related particulate matter impairs cognitive function in the elderly, Environmental Research, 109, 2009, 1004-1001

[19] Wilson, W.E., Chow, J.C., Walborne, F.W., Engelbercht, J., Watson, J.G., "Monitoring of Particulate Matter outdoors." Chemosphere.49, 2002,1 009-1043.

[20] Roy, D., \& Singh, G., "Chemical Characterization and Particulate Distribution of $\mathrm{PM}_{10}$ and $\mathrm{PM}_{2.5}$ at Critically Polluted Area of Dhanbad/Jharia Coalfield", Int. Journal of Engineering Research and Applications, 4., 3., 2014, 625634

[21] Sharma, N., Chadhary, K. K., Chalapati Rao, C. V., "Vehicular pollution prediction modelling: A review of transport dispersion models", Transp Rev (UK), 20., 4., 2004, 409.

[22] Lee, B.K. and Hieu, N.T., "Seasonal Variation and Sources of Heavy Metals in Atmospheric Aerosols in a Residential Area of Ulsan, Korea. Aerosol and Air Quality Research, 11., 2011, 679-688

[23] Yu, L., Wang, G., Zhang, R., Zhang, L., Song, Y., Wu, B., $\mathrm{Li}, \mathrm{X} ., \mathrm{An}, \mathrm{K} ., \mathrm{Chu}, \mathrm{J}$. , "Characterization and Source Apportionment of $\mathrm{PM}_{2.5}$ in an Urban Environment in Beijing". Aerosol and Air Quality Research, 13., 2013, 574583

[24] Celo, V. and Dabek-Zlotorzynska., "Concentration and Source Origin of Trace Metals in PM2.5 Collected at Selected Canadian Sites within the Canadian National Air Pollution Surveillance Program". Environmental Science and Engineering, 2010, DOI: 10.1007/978-3-642-122781_2

[25] Lough, G.C., Schauer, J.J., Park, J.S., Shafer, M.M., Deminter, J.T. and Weinstein, J.P., "Emissions of Metals Associated with Motor Vehicle Roadways". Environ. Science and Technology, 39., 2005, 826-836

[26] Mooibroek, D., Schaap, M., Weijers, E.P. and Hoogerbrugge, R., "Source Apportionment and Spatial Variability of $\mathrm{PM}_{2.5}$ Using Measurements at Five Sites in the Netherlands", Atmospheric Environment, 45., 2011, 4180-4191

[27] Sorme, L., Bergback, B. and Lohm, U., "Goods in the Anthroposphere as a Metal Emission Source: A Case Study of Stockholm, Sweden". Water Air Soil Pollution, 1., 2001, 213-227

[28] Canepari, S., Perrino, C., Olivieri, F. and Astolfi, M.L., "Characterisation of the Traffic Sources of PM through Size-segregated Sampling, Sequential Leaching and ICP Analysis", Atmospheric Environment, 42., 2008, 81618817

[29] Figueroa, D. M., O-Villanueva, M., De La., Para, M. L., "Heavy metal distribution in dust from industry in Hermisillo, Sonara, Mexico", Atmospheric Environment, 41., 2007, 276-288
[30] DHSS.chapter-8-silica-exposed workers. In: the health consequences of smoking cancer and chronic lung disease in the work place: A report of the surgeon general. MD: U.S. Department of Health and Humans Services, Public Health Services, Offices on smoking and health, 1985, 317-354

[31] Wang, W., Maenhaut, W., Yang, W., Liu, X., Bai, Z., Zhang, T., Claeys, M., Cachier, H., Dong, S., Wang, Y., "One-year aerosol characterization study for $\mathrm{PM}_{2.5}$ and $\mathrm{PM}_{10}$ in Beijing", Atmospheric Pollution Research, 5., 2014,554-562

[32] Abechi, E. S., Okunola, S. M., Zubairu, S.M.J., Usman, A. A., Apene, A., "Evaluation of heavy metals in roadside soils of major streets in Jos metropolis, Nigeria", Journal of Environment Chemistry and Ecotoxicology, 2., 6., 2010, 98-102

[33] Khillare, P. S., and Sarkar, S., "Airborne inhalable metals in residential areas of Delhi, India: distribution sources apportionment and health risk", Atmospheric Pollution Research, 3., 2012,46-54

[34] Armah, F.A., S. Obiri, D.O. Yawson, E.E. Onumah, G.T. Yengoh, E.K. Afrifa and J.O. Odoi,.. "Anthropogenic sources and environmentally relevant concentrations of heavy metals in surface water of a mining district in Ghana: A multivariate statistical approach", Journal Environment Science Health a Toxicology Hazard. Substances Environment England, 45., 2010, 1804-1813

[35] Chen, W., Liu, Y., Huang, X., Rong, Y., "Respiratory Diseases Among Dust Exposed Workers", Department of Occupational and Environmental Health, School of Public Health, Tongji Medical College in Huazhong University of Science \& Technology, China, 2005

[36] Nazir, R., Shaheen, N., Shah, H. M., "Indoor/outdoor relationship of trace metals in the atmospheric particulate matter of an industrial area", Atmospheric Reasearch, 101., 2011,765-772.

[37] Godoi, M. H. R., Braga, M. D., Markarovska, Y., Alfoldy, B., Marco, S. A., Filho, V. R., Godoi, L. F., "Inhale particulate matter from lime industries: Chemical composition and deposition in human respiratory tract. Atmospheric environment, 42., 2008, 7027-7033

[38] Hong, H., Cheng, L. S., Jun-ji, C., Chang-Wei, Z. XinGeng, C., Shao-jao, F., "Characterstics of indoor/outdoor $\mathrm{PM}_{2.5}$ and elemental components in generic urban, roadside and industrial plant areas of Guagzhou City, China", Jornal Environment Science, 17., 2007, 35-43

[39] Ahumada, H. T., Whitehead, L., Blanco, S., "Personal exposure to $\mathrm{PM}_{2.5}$ and elemental composition- A comparison between outdoor and indoor workers from two Mexican cities. Atomspheric Environment, 41., 2007, 74017413

[40] Adgate, J. L., Mongin, S. J., Pratt, G. C., Zhang, J., Field, M.P., Ramchandran, G., Sexton, K., "Relationship between personal, indoor and outdoor exposure to trace elements in $\mathrm{PM}_{2.5}$ ", Science of the Total Environment, 386., 2007, 2132

[41] Molnar, P., Gustafson, P., Johannesson, S., Boman, J., Barregard, L., Sallsten, G., "Domestic wood burning and $\mathrm{PM}_{2.5}$ trace elements personal exposure, indoor and 
outdoor levels", Atmospheric Environment, 39., 2005, 2643-2653

[42] Molnar, P., Gustafson, P., Johannesson, S., Boman, J., Barregard, L., Sallsten, G., "Personal exposures and indoor residential outdoor and urban back-ground levels of fine particles trace elements in the general population", Journal Environment Monitoring, 8., 2006, 543-551

[43] Abdul-Wahab, A.S., Yaghi, B., "Total suspended dust and heavy metal levels emitted from a workplace compared with nearby residential houses", Atmospheric Environment, 38., 2004,745-750.

[44] Deng, W. J., Louie, P.K.K., Liu, W.K. Bi, X.H., Fd, Wong, M.H., "Atmospheric levels and cytotoxicity of PAHs and heavy metals in TSP and $\mathrm{PM}_{2.5}$ at an electronic waste recycling site in Southeast China", Atmospheric Environment, 40., 2006, 6945-6955. 